\title{
No, pero he visto la película
}

\author{
Laurene Krasny-Brown
}

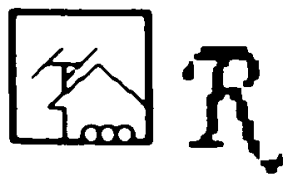

Las relaciones entre la afición a la lectura y la afición al cine $y$ a la televisión se ven a menudo como divergentes $y$ competitivas. Un mejor conocimiento de las características psicológicas y representacionales de cada medio y de los efectos reales del cine y la TV sobre la lectura puede ayudarnos a intervenir más eficazmente sobre las actividades del niño con los medios de comunicación. Este artículo (uno de los capitulos de un original y útil libro sobre cómo usar los medios en educación) revisa los efectos diferenciales del libro $y$ el film en el niño, e incluye una serie de propuestas didácticas y actividades prácticas.

Siempre que se habla de la educación de la audiencia joven, las imágenes en movimiento suelen recibir infinidad de críticas: los programas televisivos son demasiado violentos y en las películas abundan los contenidos sexuales; los anuncios exacerban hasta la saciedad la predilección infantil por las golosinas y acaban generando caries; las películas exacerban, a su vez, las reacciones emocionales, y terminan causando pesadillas. "Ver la tele» es un odioso y pasivo hábito que roba el tiempo de los niños y atenta contra su imaginación y capacidad de concentración. Las quejas contra las películas y la televisión por parte de quienes las conciben como una amenaza para la enseñanza, parecen más significativas y frecuentes que las alabanzas de sus hipotéticas virtudes.

Pero, ¿qué pasaría si el contenido de los programas no planteara problemas y se hicieran historiàs de ficción infantiles de mucha mayor calidad que las actuales, tanto en el celuloide como en cintas de vídeo? ¿Qué pasaría si la pantalla les sugiriera comer zanahorias en lugar de chocolatinas? ¿Y qué pasaría si el tiempo no fuera tampoco el problema y los niños repartieran equitativamente su horario entre los productos visuales y sus lecturas? ¿Nos seguiriamos muchos de nosotros sintiendo satisfechos alejando a los más jóvenes de la pantalla? ¿Hay algo que desvalorice intrínsecamente a una historia desde el punto de vista intelectual por el mero hecho 
de que sus personajes aparezcan en movimiento dentro de un espacio narrativo?

\section{LA IMAGEN EN MOVIMIENTO}

¿Qué es lo que los niños aprenden en una película o en la televisión que no aprendan en un relato escrito? Consideremos la forma en que cada medio narra una historia. La ficción escrita indaga en las posibilidades de cualquier acción humana, pero el movimiento de sus protagonistas es, en el mejor de los casos, una imagen mental que el lector se forja en su interior a partir de las palabras. Las ilustraciones de un libro pueden sugerir o llevar implícito el movimiento, como ocurre cuando el personaje aparece en la ilustración con las extremidades flexionadas en algún sentido, a pesar de lo cual cada imagen sigue siendo estática y aislada. Por contra, la ilusión del movimiento es consustancial al despliegue de imágenes continuas que el cine y la televisión posibilitan: cuando a una imagen estática le sucede otra con mucha rapidez ligeramente distinta, el ojo interpreta dicho cambio como un movimiento. La televisión, el cine y los dibujos animados difieren entre sí en algunos aspectos; la imagen del vídeo es menos densa que la del cine, y la de los dibujos animados es, como su nombre indica, un dibujo y no un elemento vivo. Pese a ello, todas consiguen proyectar una imagen dinámica.

\section{La acción de los personajes}

El cambio de la página impresa a la imagen en movimiento afecta al contenido de la historia. Las imágenes en movimiento dan cuenta de ciertos aspectos de un argumento más fácilmente que otro tipo de imágenes. Por ejemplo, cuando la imagen se mueve, podemos apreciar qué es exactamente lo que están haciendo los personajes; el diálogo en cambio se apoya mucho menos en el movimiento directamente apreciable; de hecho, cualquier parlamento dicho en la pantalla suele requerir que el actor disminuya el paso. La labor de un guionista cinematográfico consiste, en muchos casos, en adaptar el contenido de la historia escrita a las técnicas de producción características de la pantalla.

Las imágenes y el texto de las figuras 1 y 2 han sido seleccionadas de una película de dibujos animados inspirada en el cuento popular $A$ Story a Story (Historia de una historia). En ellas queda claro que Ananse, el pro-

Figura 1

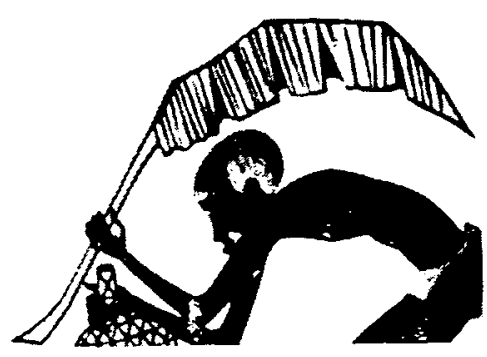

Figura 2

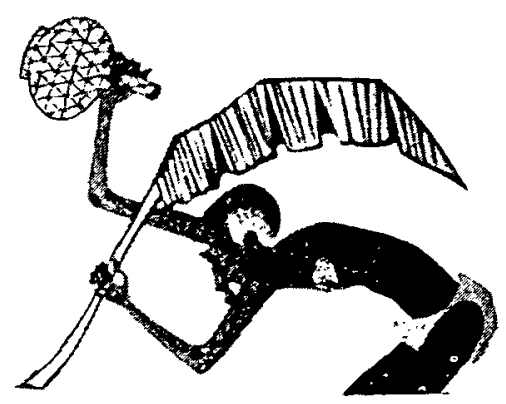


tagonista del cuento, "coge» y "vierte» algo. Compárese estos fotogramas con la ilustración asociada al mismo texto (ver Fig. 3). El dibujo animado permite visualizar más verbos activos involucrados en la historia que se narra.

Dicho comportamiento visible no pasa inadvertido entre los niños. Un grupo de ellos de entre seis y diez años, que vieron este cuento popular en un dibujo animado, daban cuenta de un mayor número de acciones de los personajes al resumir la historia que otro grupo de niños a los que se les presentó el libro con ilustraciones de la misma historia. Igualmente, los espectadores imitan los gestos que ven hacer a los personajes.

Para poder medir el impacto de la animación per se en el aprendizaje, las dos versiones de la historia a comparar tienen que ser idénticas en los demás rasgos: tipo de ilustraciones, texto y narración. La película seguía fielmente el libro; según el director, "procurábamos siempre que la película fuera el resultado de un libro de ilustraciones proyectado". Pese a esos criterios rígidos en la elaboración de la prueba, la memoria de sucesos narrativos mejoró tras ver a los personajes en acción, tanto en los pequeños como en los mayores.

Las acciones que se ven en cine o televisión se recuerdan mejor que las que se emiten por radio, tanto en los niños preescolares como en los de $5 .^{\circ}$ curso. Este sesgo en el aprendizaje se mantiene también en las secuencias de hechos: los niños preescolares recuerdan con más precisión el orden de los episodios de una historia cuando el contenido se presenta visualmente que cuando éste se narra.

Sin embargo, los espectadores no necesariamente utilizan el vocabulario de la historia para recordar las acciones de los personajes (recuérdese que los niños tendían a recordar mejor el léxico empleado por un autor después de haber oído la historia que después de haberla visto representada). Por ejemplo, varios niños que vieron por televisión A story a story, utilizaron para describir el momento representado en las figuras 1 y 2 palabras tales como "roció..." o "esparció..." agua en la hoja del plátano. Teniendo en cuenta que, si se fija uno bien, en los dibujos animados aparecen gotas de agua, me siento tentada a especular que la elección de verbos alternati-

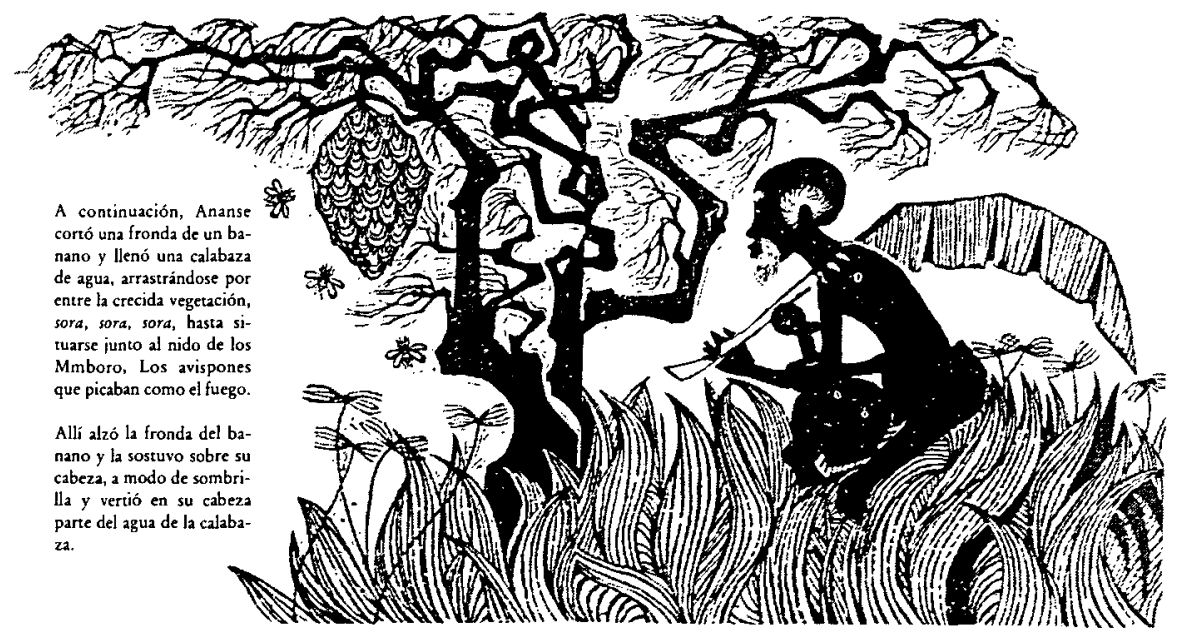


vos no era un error en el recuerdo, sino que se basaba en lo que realmente parecía que Anansa estaba haciendo -no vertiendo el agua, sino esparciéndola gota a gota. Otra prueba de la "lectura» que los espectadores hacían de la imagen recordada es su narración literal del lugar donde caía el agua, no sobre la cabeza del personaje, como el narrador decía, sino sobre la hoja del plátano. ¿Por qué los niños tienden a recordar mejor una acción filmada? No sería descabellado pensar que los sucesos de una historia filmada fuesen más difíciles de retener que los escritos o radiados: ambos, dibujo y sonido llevan implícito un significado, suceden varias cosas a la vez y los hechos progresan a su propio e implacable ritmo. Pero aunque estos aspectos de la acción fílmica hagan de la comprensión de la historia una difícil tarea, otros rasgos lo compensan.

Los hechos en la pantalla pueden reforzar un mensaje verbal. Los niños recuerdan los contenidos importantes de televisión mejor cuando los personajes actúan y hablan, que cuando los personajes se limitan a hablar. Si las ilustraciones facilitan el aprendizaje del texto, las imágenes en movimiento ayudan todavía más. Sin embargo, lo que los personajes hacen en pantalla no siempre es consistente con las palabras que se dicen, incluso puede que no se diga nada: raramente hay tiempo para ponerse a discutir en una escena de caza. Pero los niños recuerdan muy bien incluso esos hechos que no aparecen en los diálogos, ¿por qué? En parte porque hay más atención. Los movimientos visibles atrapan nuestra mirada. Los niños de todas las edades prestan más atención a la pantalla cuando hay altos niveles de actividad física; la acción en pantalla acompañada de efectos sonoros y música atrae la atención de los preescolares con más probabilidad que los contenidos violentos. Comparativamente los niños miran menos cuando los adultos que aparecen en pantalla están sentados y hablando tranquilamente, aunque la conversación de esos adultos sea sobre la acción de luchar, en la medida en que las acciones que describen no pueden observarse directamente.

Ocurre también que el resultado de las acciones que se filman es tan vívido que los espectadores, por jóvenes que sean, pueden reconocer fácilmente lo que está ocurriendo, y lo que se comprende se recuerda con más facilidad. Cuando la imagen que aparece en televisión y la banda sonora son incompatibles, es la imagen lo que predomina al ofrecer menor resistencia a la atribución de significado.

\section{El valor de los rostros}

Las imágenes en movimiento describen además contenidos no accesibles a la radio o a lo impreso. Un personaje que aparece en pantalla forzosamente tiene una apariencia, viste de determinada manera (a menos que se trate de un patito feo, de un corcel negro o de un alienígena desnudo), y aparece en determinados escenarios. El porte físico de una persona, en la ficción como en la realidad, indica su edad, salud, posición social e incluso personalidad. Y esto simplemente con su presencia. Si además mueve o alza las cejas, está manifestando con ese gesto sus pensamientos y emociones más íntimos: la conducta de un personaje abarca mucho más que la simple acción. La imagen de un actor en la pantalla puede también ser manipulada mediante el uso de planos cortos, iluminación, música y otras técnicas de 
producción. La animación ofrece aún más posibilidades de simplificación o exageración de los personajes. Cuando un dibujante de tiras quiere reflejar expresión facial, enfatiza los rasgos - aquellos que se pueden movercomo lo haría un actor: ojos, boca y cejas. Como veremos, incluso los rasgos expresivos más sutiles en una figura animada pueden tener valor emocional para el espectador (Fig. 4).

Los escritores de ficción tienen más opciones a la hora de caracterizar a sus personajes. La apariencia de la heroína puede ser definida con todo detalle o ignorada por completo. A diferencia de lo que sucede con la imagen de esa misma heroína en la pantalla, donde su imagen resulta ineludible, en la página impresa es el autor quien elabora a discreción su apariencia. De hecho, en ocasiones se sugiere a los autores que supriman por completo cualquier explicación al respecto: "Un buen escritor puede salir airoso y conseguir lo que se propone sugerir apelando únicamente a la acción y el diálogo, y (...) dejar las explicaciones a sus críticos y revisores. Cuando, a pesar de tales consejos, un autor determinado describe a la heroína de una historia, esa descripción suspende momentáneamente el curso narrativo. Los hechos que configuran la historia se detienen, aun cuando prosiga la lectura o se siga escuchando la narración.

He aquí, pues, dos enfoques posibles de cómo describir a los personajes: el de la película, que nos da a conocer infinidad de detalles visuales a medida que la historia avanza, y el del libro, que selecciona algunos detalles para intercalarlos entre los hechos que tienen lugar en la historia. Supongamos, a efectos de comparación, que un mismo personaje se halla enfrentado a un mismo dilema en estos dos tipos de medios. ¿Reaccionan los niños en forma distinta a estas caracterizaciones alternativas? Así es.

Los espectadores de menor edad se apoyan en el contenido visual de las imágenes en movimiento para entender a los personajes de una historia. En comparación con el público infantil enfrentado a emisiones radiales o incluso a libros ilustrados, aquellos niños que reciben la historia por vía fílmica o televisiva basan más sus inferencias en la apariencia física de los personajes y en su comportamiento. Por ejemplo, la manera en que se ejecuta una acción a menudo revela si es fácil o difícil. Pregunté a un grupo de niños si colgar al leopardo había costado trabajo o había sido fácil para Ananse después de que hubieran visto la película de dibujos animados o hubieran escuchado la lectura del libro de ilustraciones, basados ambos en $A$ Story a Story (ver fotogramas en las figuras 5 a 8 . En la película, el protagonista tira cuatro veces de la soga. En el libro aparece tan sólo la última imagen). Los dos tipos de público, el de los dibujos animados y el del libro, se basaban en datos distintos para sus conclusiones. Los espectadores de la película se referían sistemáticamente al comportamiento observado: "Le resultó difícil", decían, porque "parecía que estaba luchando" o "por

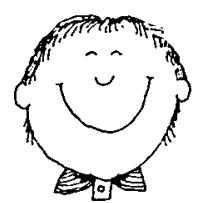

Feliz

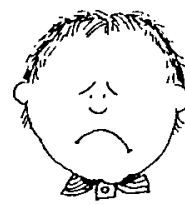

Triste

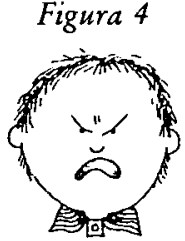

unare Broun

Enfadado

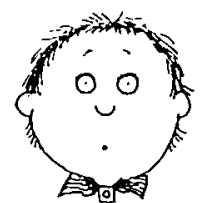

Sorprendido

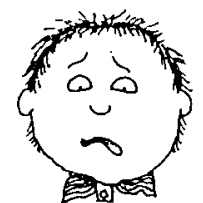

Asustado 


\section{2}

Figuras

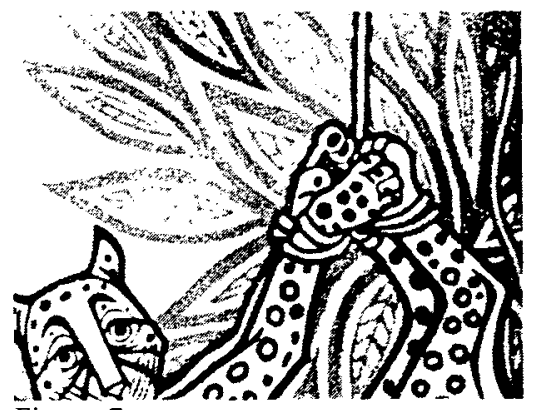

Figura 7

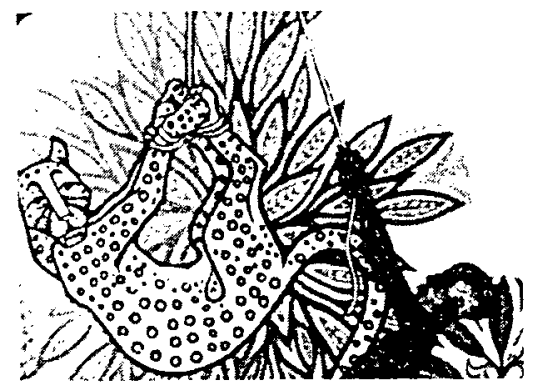

Figura 6

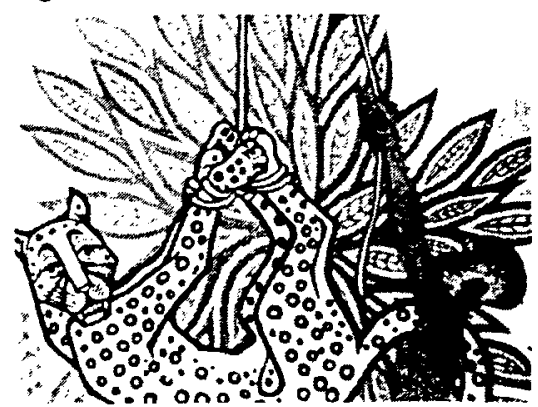

Figura 8

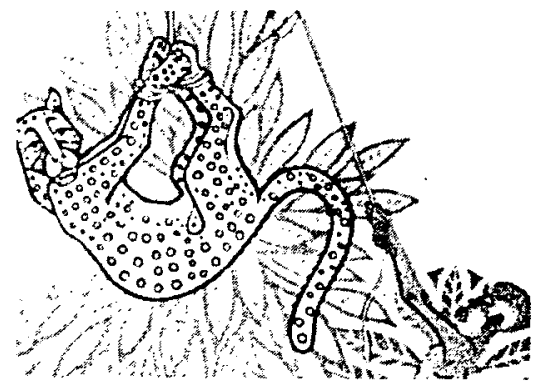

la forma en que tiraba de la soga». El público del libro recurría las más de las veces a importar pruebas ajenas a la historia: «Difícil», porque «los leopardos pesan muchísimo»o "porque pueden darte un mordisco». También aludían con mayor frecuencia al diálogo — «Difícil, porque el Dios del Cielo le había dicho que él mismo era débil»-, aun cuando el contenido lingüístico fue idéntico para ambos grupos.

Cual improvisados fisonomistas, los niños escrutan la apariencia de los personajes fílmimos o televisivos para extraer conclusiones de tipo demográfico: «En la antigüedad usaban ese tipo de ropa» o «Llevaba zapatos de madera, así supe que era ( $i$ !) escocés» (aun cuando se describa la vestimenta de los personajes, los que escuchan una emisión radial suelen basarse en razonamientos de orden más general: «Ocurría en la antigüedad porque era entonces cuando había pececillos mágicos por ahí»). La barba, los senos y otros signos de madurez les proporcionan indicios de la edad de un personaje: "Era muy joven, porque no tenía bigote ni barba». La musculatura y el vigor físico son indicios de la fuerza de otros: «Era débil, porque se le traslucían los huesos» o "Era fuerte, por la forma en que acarreó todas esas cosas». Los espectadores de menor edad interpretan fácilmente, si bien no siempre con exactitud, ciertos detalles físicos irrelevantes pero reales, que las producciones fílmicas reproducen minuciosamente.

¿Y de llegar al corazón de un personaje, qué? La apreciación de cualidades personales como la edad, la fuerza y el atractivo de cada uno contribuye a perfilar de manera muy superficial a los personajes de cualquier historia. ¿Cuán bien entienden los niños los sentimientos del héroe o heroína de una película?

Los niños de menor edad reconocen las emociones de los personajes a partir de sus expresiones faciales. A los seis años, aproximadamente, logran identificar con bastante exactitud la alegría, la tristeza, el enfado, el temor 
y el asombro en los rostros que observan, aun cuando a veces confundan el enfado y el temor. De hecho, los espectadores de menor edad que interpretan los sentimientos de un personaje, tienden a basarse en las emociones abiertamente manifiestas (en la expresión facial, en los gestos o en las posturas) y a dejar de lado todas las claves res̀tantes, incluida la situación que suscitó dichos sentimientos. En cierto sentido, las películas capitalizan la tendencia del niño a quedarse con las emociones que le sugieren las expresiones faciales; un único y conmovedor acercamiento de la cámara (closeup) $o$ un gesto igualmente dramático suele constituir para ellos una evidencia suficientemente convincente. A medida que los jóvenes espectadores van creciendo, aprenden a inferir los sentimientos de los personajes a partir de múltiples claves, incluida la manifestación externa de sus emociones, sus posibles motivaciones y la situación en la que se hallan inmersos. La atmósfera o el tono afectivo de una historia se ve también realzado por las voces, la música, los efectos sonoros y visuales que posibilitan las cámaras, la ilu- . minación y el montaje del material fílmico. Quizá ocurre que, a medida que aumenta nuestra experiencia como espectadores, aumentan también los ingredientes que contribuyen a que podamos empatizar con los personajes fílmicos o televisivos.

He aquí un ejemplo de cómo los niños interpretan las emociones de los personajes en la pantalla. Un grupo de niños en edad pre-escolar y otros entre nueve y diez años tomaron parte en una investigación en la que a la mitad de ellos se les hizo ver una versión en dibujos animados de The Three Robbers (Los tres salteadores) y a la otra mitad se le leyó en voz alta el libro con ilustraciones en el que se había inspirado esa película. Luego se pidió a todos los niños que dijeran cómo creían ellos que se sentía la pequeña Tiffany al encontrarse con los salteadores (ver los fotogramas en las figuras 9 a 12. En el libro aparecía una ligera variante del primer fotograma). La narración en ambas versiones era la siguiente:

Pero una noche más amarga y negra que otras, los salteadores detuvieron un carruaje en el que viajaba tan sólo un pasajero, una huerfanita llamada Tiffany. Iba, en esos momentos, a casa de su tía, una mujer perversa, para quedarse a vivir con ella. Y quedó simplemente encantada de toparse con los salteadores.

Los dos sub-grupos tendieron a extraer conclusiones similares, pero por caminos distintos. Los niños que vieron el dibujo animado en un televisor aludieron, en su mayoría, a la evidencia visual al enjuiciar los sentimientos de Tiffany, citando, como prueba de su reacción confiada, carente de temor, el débil esbozo de una sonrisa en su rostro - "Comenzó a sonreír»y el gesto hipotéticamente amistoso de acercar su muñeca a la ventana: «Le enseñó a uno de ellos su muñeca». Como contrapartida, los niños que escucharon la historia trajeron a colación, en su mayoría, el correspondiente texto: "Se decía que estaba encantada". Además, los auditores de mayor edad hicieron inferencias de mayor alcance: «No quería ir a casa de su tía» o "No sabía que eran salteadores".

Cabe advertir aquí algo. Los niños tienden a no explicitar información de tipo psicológico sobre los personajes de una historia. Cuanto más pequeños sean, mayor será la tendencia a restringir sus descripciones a las acciones de los personajes, el diálogo y las reacciones físicas evidentes. Los 


\section{4}

Figura 9

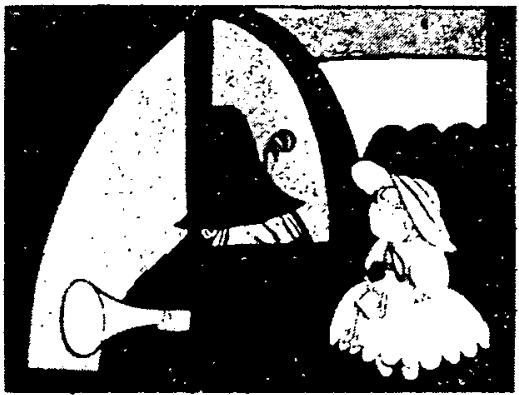

Figura 11

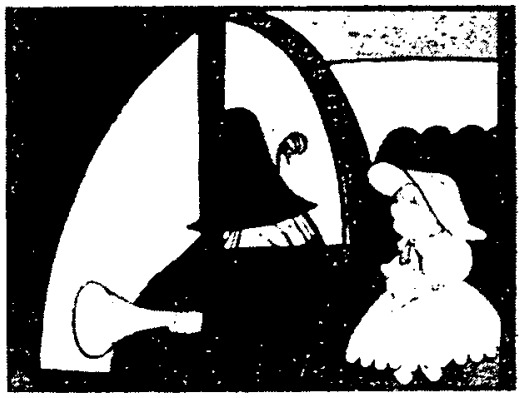

Figura 10

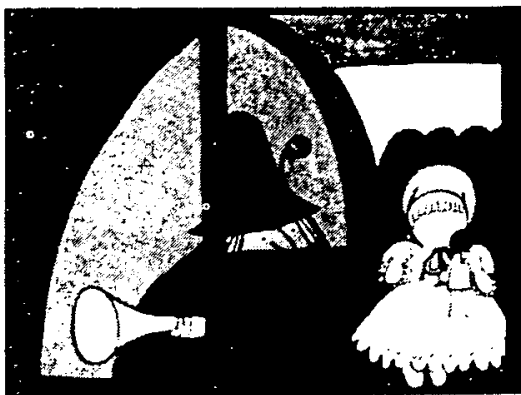

Figura 12

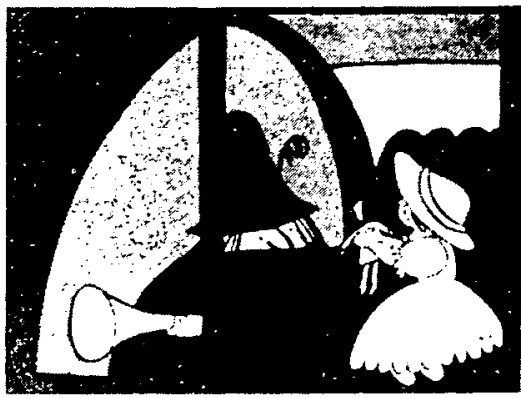

adultos pueden en cualquier caso establecer un diálogo con ellos y sonsacarles, o ayudarles a articular, lo que han entendido sobre las motivaciones, los pensamientos y sentimientos de los personajes.

\section{ALGUNAS FUENTES DE CONFUSION}

\section{La imagen que ofrece la cámara}

La misma cualidad verosímil que hace de las imágenes en movimiento algo tan fácilmente asimilable puede contribuir a desorientar a los espectadores de menor edad en su percepción de lo que estén viendo. La aceptación en exceso literal de la imagen en pantalla confunde a los niños tanto respecto a los objetos como a los hechos. A modo de ejemplo, considérese el tamaño que un objeto cualquiera adopta en la pantalla del televisor: al comparar dos imágenes de una barrita de chocolate filmada en vídeo a distancias variables de la cámara, los niños del $2 .^{\circ}$ año básico y de niveles inferiores tienden a percibir en mayor grado la barrita como algo comestible cuando es filmada en close-up (imagen de mayor tamaño) que cuando la toma se ha hecho desde mediana distancia (imagen de menor tamaño). $Y$ únicamente cuando son un poco mayores los niños pueden obviar estas diferencias aparentes en el tamaño de las imágenes. Incluso los espectadores adultos se equivocan en ocasiones e interpretan el contenido fílmico como si no hubiera ninguna cámara de por medio. Por ejemplo, puede que no perciban las distorsiones a que da lugar una toma hecha con una lente gran angular.

\section{Las traslaciones de tiempo y espacio}

Otra confusión habitual entre los espectadores infantiles es consecuencia del proceso de edición del material visual. Lo que uno ve finalmente de 
una historia, a menos que ella se inscriba en la corriente del cinéma-verité, no es un registro exhaustivo de los acontecimientos. Al editar una ficción cinematográfica o televisiva, se seleccionan tan sólo aquellos segmentos de la trama que mejor representan la narración globalmente considerada. El editor fílmico trabaja para seleccionar la información precisa: para que no sea excesiva y aburra a los espectadores, o resulte tan escasa que les resulte frustrante. Al unir dos fragmentos escogidos de una película o un vídeo consigue transferir instantáneamente la acción narrativa de un sitio y una época a otros, independientemente de que el personaje se desplace de una habitación a otra o de un planeta a otro. Los medios impresos y auditivos llenan de igual modo esta brecha espacio-temporal al contar una historia. Los capítulos de un libro suelen retomar la historia en otro punto: "Poco después...». Pero las acciones finalmente editadas al procesar el material visual aparecen en un continuo ininterrumpido:

Hacer un corte armónico equivale a unir dos tomas de modo tal que la transición entre ambas no provoque un salto ostensible y el espectador conserve la ilusión de estar viendo una secuencia ininterrumpida de acciones.

Esta ilusión de una secuencia ininterrumpida surte algún efecto en la percepción infantil del tiempo. En varias investigaciones desarrolladas en Harvard, niños de entre nueve y doce años hubieron de estimar la duración de los acontecimientos en una historia. A algunos les fueron presentados tales acontecimientos en una película; a otros les fueron descritos en una cinta grabada para que la oyeran o en un libro con ilustraciones y las preguntas formuladas adoptaban normalmente la siguiente forma: « Cuánto tardó Ananse en llegar hasta el Dios del Cielo?» o « ¿... la bandada de gansos en su viaje?" o " $\dot{c}$... los salteadores en detener un carruaje y desvalijar a sus ocupantes?», seguidas de otra pregunta fija: «¿ Cómo lo sabes?».

Por ejemplo, he aquí a los ladrones de Los tres salteadores deteniendo a un carruaje para saquear a sus ocupantes. Las ilustraciones y el texto de las figuras 13 a 15 aparecen en el libro ilustrado que se utilizó.

\section{Figura 13}

Para detener el carruaje, los salteadores arrojaron pimienta a los ojos del caballo
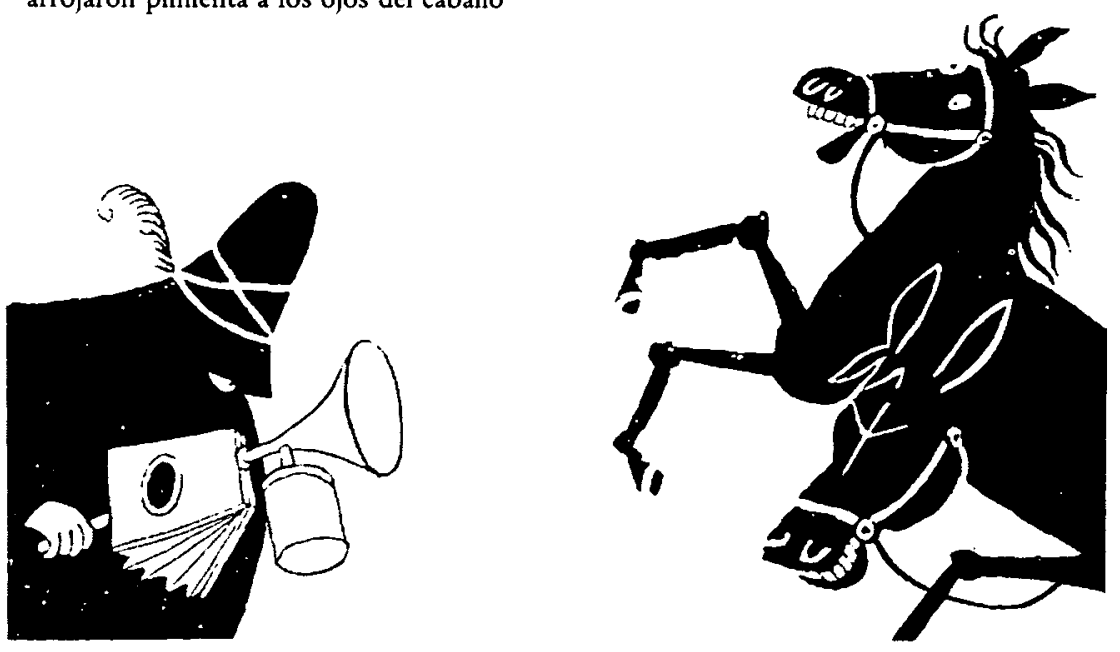


\section{6}

Figura 14
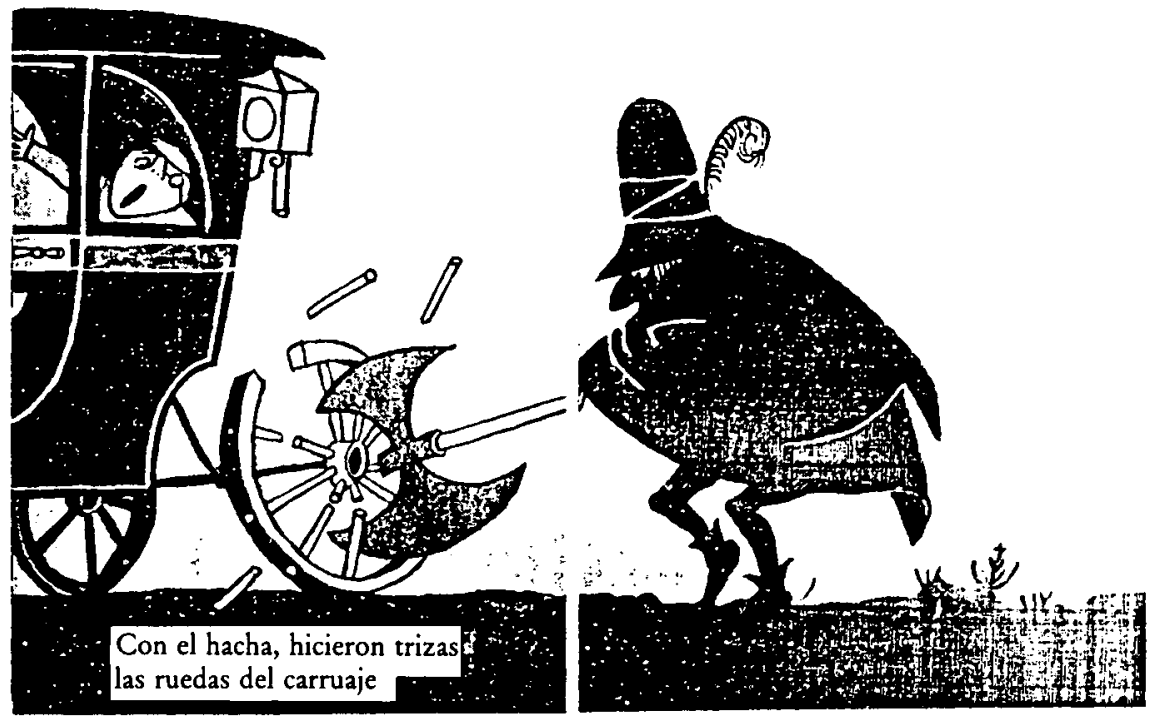

Figura 15
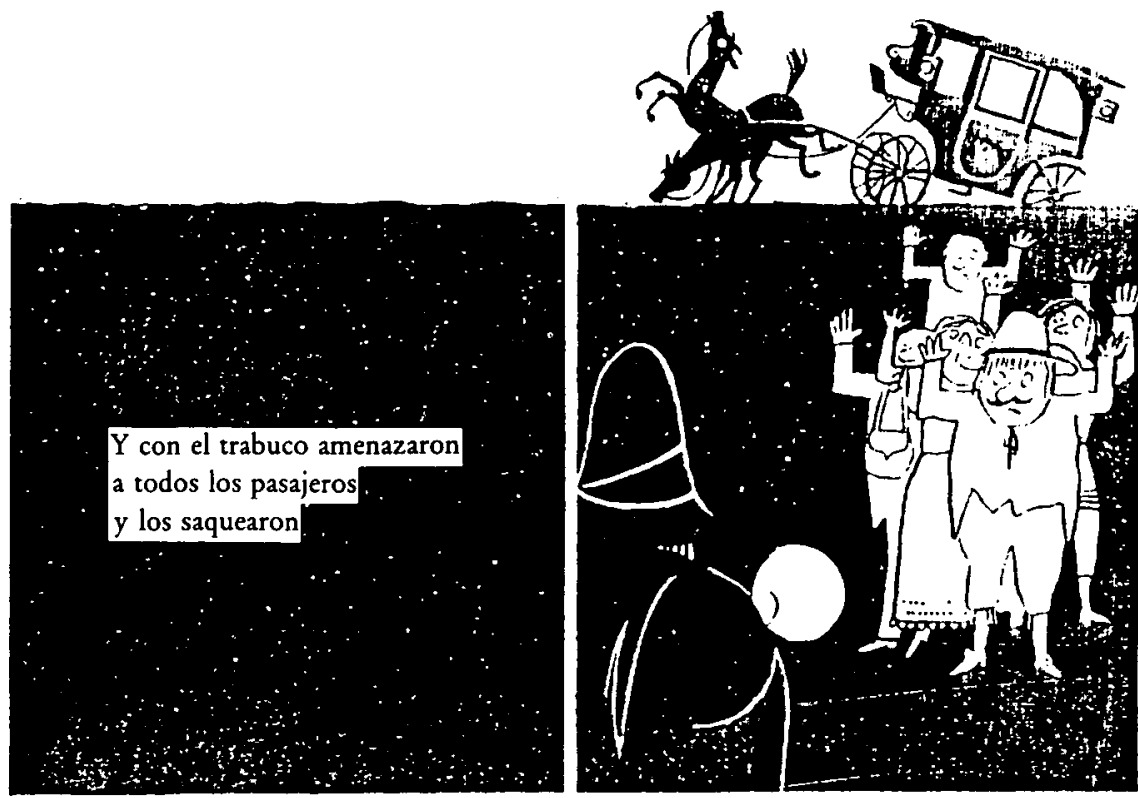

La película ilustraba la acción de los villanos a través de un dibujo animado, con imágenes como las que nos enseñan las figuras 16 a 19 . En la banda sonora se oye exactamente el mismo texto escrito que se utiliza en el libro.

Los espectadores infantiles de la película supusieron, en su mayoria, que los salteadores habían concluido su fechoría en menos de cinco minutos, y algunos estimaron el tiempo total en tan sólo unos pocos segundos. En cambio los auditores, aunque habían visto ilustraciones, ampliaron su duración 


\section{7}

Figura 16

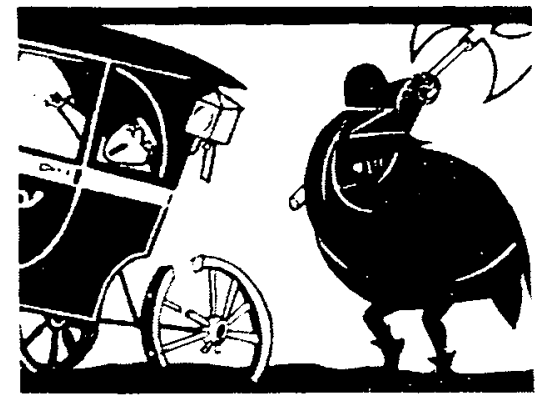

Figura 18

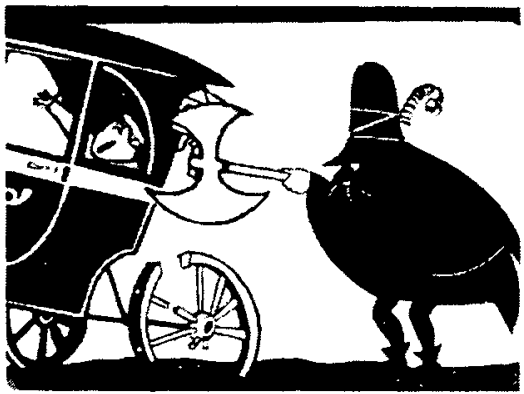

Figura 17

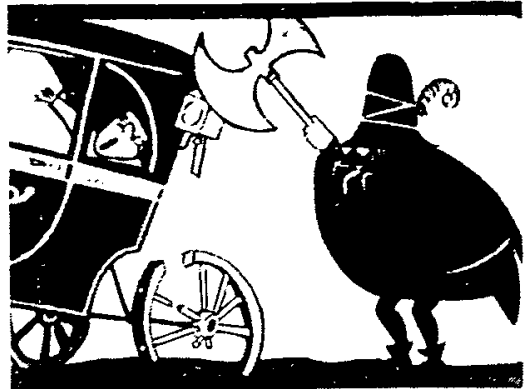

Figura 19

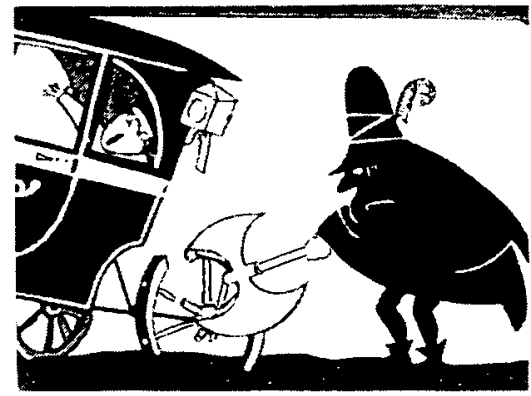

a lapsos tan considerables como un par de horas. En ambas instancias, los espectadores de la película cuyas edades oscilaban entre los nueve y los doce años hicieron estimaciones temporales más breves que las de sus pares en el grupo de auditores, sobre los mismos acontecimientos.

El razonamiento de los niños explica en parte estas diferencias perceptivas. Los espectadores justificaban sus estimaciones más breves del robo, con razones como: «Es que ocurrió todo tan rápido en la pantalla» o «Se los veía caminando a toda prisa». Así pues, los espectadores confunden la duración de los acontecimientos ficticios con el tiempo que lleva presentarlos en la pantalla, en virtud de lo cual acaban estimando la duración de los acontecimientos ficticios según el tiempo real. Los niños que escucharon la historia mostraron cierta tendencia a considerar cuánto pueden durar en sí mismas las acciones narradas y tienen en cuenta distintos aspectos de la situación que se narra, como su dificultad - «No es fácil detener a un carruaje»-y las distintas etapas que ello supone: «Tuvieron que hacer pedacitos las ruedas y lo demás". Incluso las estimaciones más cortas de los sujetos auditores nos sugieren la presencia de un cierto pragmatismo lógico: «Hay que actuar rápido (si eres un salteador); si no, te cogen».

Es como si la presentación de los hechos en el soporte fílmico neutralizara el dominio de las nociones temporales que los niños de mayor edad han conseguido ya en su desarrollo. Todos esos niños sabían decir la hora y entendían las palabras utilizadas en la medición del tiempo, algo que fue comprobado con anterioridad al experimento. En cualquier otra circunstancia, los niños de esas edades razonan lógicamente en torno al tiempo transcurrido. Otro tanto sucedía con los sujetores auditores. Sin embargo, el enjuiciar la duración de una historia en una pantalla, muchos niños de mayor edad se fijan tan sólo en una clave en particular - el movimiento filmado- y cometen, por tanto, errores de estimación típicos de los niños 
de menor edad. Se diría que sucumben a la ilusión que las imágenes en movimiento sugieren de una acción ininterrumpida en el tiempo y el espacio.

\section{Una pausa para la publicidad y volvemos}

Lo mejor de alguna pieza dramática es habitualmente interrumpido en la televisión por los anuncios publicitarios, como todos sabemos muy bien. Y aparte lo ya dicho, en el sentido que la visión de una historia en la pantalla comprime el argumento para el público infantil, la introducción de material extraño les hace perder el hilo. Los niños más pequeños tienen más dificultades para relacionar las motivaciones de un personaje determinado, sus acciones y las consecuencias resultantes cuando dichos elementos quedan separados temporalmente por una pausa publicitaria. Cuando un grupo de investigadores re-editó un episodio televisivo para eliminar esas interrupciones - por ejemplo, entre las perversas motivaciones de un personaje y su conducta violenta posterior-, comprobó que el espectador de menor edad entiende mejor cómo se relacionan tales acontecimientos y puede evaluar más negativamente al agresor. Las interrupciones a causa de la publicidad no son del todo irreparables, pues los niños más pequeños captan los dramas complejos en forma bastante más fragmentaria que los adultos, independientemente del medio utilizado, y hacen menos inferencias sobre las relaciones posibles entre los acontecimientos que configuran la historia. De todas formas, tales interrupciones en mitad de una ficción televisiva constituyen, de hecho, un estorbo para su comprensión de la historia.

Este último ejemplo nos lleva a una cuestión bastante más esencial. La mayor o menor comprensión del cine y la televisión por parte de los niños depende de múltiples factores, incluyendo el hecho de si pueden atribuir sentido a determinadas técnicas de producción -como las transiciones a que da lugar la edición fílmica - o de aplicar habilidades generales de pensamiento y conocimiento del mundo. Lo que diferencia el aprendizaje infantil a partir de la pantalla, en oposición al que tiene lugar con otros medios, es la relativa facilidad con la que el niño alcanza un cierto nivel de comprensión.

\section{LOS AUDIOVISUALES Y LA LECTURA}

¿Influye en algo sobre su rendimiento escolar el tiempo que los niños pasan viendo televisión en sus casas? Es ciertamente preocupante, en más de un sentido, la enorme cantidad de horas que los niños pasan actualmente enfrente del aparato, en la medida que todo ello afecta a sus indices de lectura. Y no puede ser de otro modo.

Pero la respuesta a esa pregunta inicial no es tan sencilla.

Por una parte, el efecto de la televisión sobre los niños es difícil de evaluar. Es un medio tan difundido en los hogares contemporáneos que incluso los espectadores televisivos ocasionales llegan a ver o saber tanto del mundo televisivo como para sufrir sus efectos. ¿Y qué es exactamente lo que deberíamos evaluar? ¿Lo mucho o poco que los niños pasan ante la pantalla? ¿Existe una relación directa del tipo: a mayor tiempo viendo la televisión, más bajo el índice de lectura? ¿Es importante, por otra parte, lo que ven, ya sea una dieta estrictísima de programas para la enseñanza de la lec- 
tura, como el que patrocina The Electric Company, o los seriales televisivos de aventuras? Posiblemente, el momento en que los niños se instalan ante la pantalla son una variable importante. Así, por ejemplo, el hecho de quedarse viendo televisión hasta tarde por la noche puede hacer que estén cansados al otro día al levantarse para ir a la escuela. Una cosa parece cierta: la relación entre el hecho de ver la televisión y el rendimiento escolar nos plantea tantos problemas como oportunidades educativas.

\section{Tiempo para practicar la lectura}

Aprender a leer requiere práctica. Dado que la lectura de palabras exige habilidades decodificadoras distintas a las que exige la "lectura» de imágenes en movimiento, el tiempo que los niños dedican a ver la televisión es tiempo que restan a sus prácticas de lectura. Es cierto, pero ello no ha conseguido alejar definitivamente a los niños de los libros. No hay evidencia alguna de que la actividad infantil de lectura ajena al ámbito escolar, prescindiendo ciertamente de la lectura de comics, haya decrecido entre la población escolar. Incluso cuando el nivel de lectura desciende en el seno de una comunidad determinada por la llegada de la televisión, éste tiende a resurgir una vez que el medio recién introducido deja de constituir una novedad. Con todo, la lectura como pasatiempo ha sido siempre una actividad de menor importancia para los niños, incluso antes de que surgiera la televisión, y aún lo es. Ocurre, simplemente, que el tiempo dedicado no es el suficiente como para que la televisión lo desgaste. No debe interpretarse todo esto como una sugerencia.a los padres para que no limiten el tiempo que sus hijos dedican a ver la televisión o no promuevan la lectura entre ellos. Ese hechó simplemente nos permite descartar la idea equivocada de que, en lugar de ver televisión, los niños de antes solian leer entre tres y cuatro horas diarias.

Es más, la lectura y la visión de ciertos materiales son actividades psicológicas completamente distintas. Y ciertas habilidades requeridas para entender una historia, como llevar el hilo de los sucesivos acontecimientos, entran en juego aunque la historia en cuestión esté impresa o sea presentada en celuloide o vídeo.

\section{El interés por la lectura}

Aprender a leer exige cierta motivación. Los niños que saben qué libros quieren leer añaden un incentivo adicional a la tarea. Se suele adjudicar a la televisión el mérito de estimular a los niños a hacer lecturas relacionadas con lo que han visto en la pantalla. A juzgar por los títulos que más se venden en librerías o los que más se solicitan en bibliotecas, la televisión y el cine inducen en la misma medida el comportamiento de niños y adultos. Pero ello plantea un problema potencial. Mientras que un atractivo drama en la pantalla puede activar el ansia de los espectadores infantiles por conocer la versión escrita, bien puede ocurrir que el libro sea de calidad muy inferior. El riesgo es todavía mayor en el caso de aquellos niños que ven mucha televisión (tres o más horas diarias) pero leen muy poco (menos de dos libros al mes). Según indica al menos una investigación desarrollada al respecto, tales niños eligen ficciones más pobres en lo que se refiere a la 
creación de personajes, el argumento y a las ideas involucradas. Todas mis sospechas apuntan a que muchos de estos espectadores ávidos y lectores infrecuentes escogen como lectura las versiones noveladas de lo que ven en la televisión y el cine. Estos subproductos de la pantalla suelen estar mal escritos y ser promocionados con abundancia de recursos. Por una parte, la televisión puede conducir a un lector reticente a libros de calidad inferior. Por la otra, puede tratarse de un niño que, si no fuera por la televisión, estaría leyendo sólo comics. En ambos casos, parece ser que la televisión estuviera remitiendo al público infantil no a una mayor cantidad de libros, sino a diversos tipos de libros.

La televisión es, qué duda cabe, un poderoso factor de ventas. El medio es igualmente capaz de despertar el entusiasmo por los clásicos de la literatura infantil como por lecturas de segunda fila. Depende, y es deber, de los editores mantener la calidad literaria de los libros relacionados con las imágenes en movimiento que brinda la televisión, libros que, hoy por hoy, constituyen las primeras lecturas informales de los pequeños lectores estadounidenses.

\section{Apoyo familiar a la lectura}

Aprender a leer exige esfuerzo y habilidad. Posiblemente, la ayuda que la familia brinda a los niños pequeños al aprender a leer incide más en sus rendimientos de lectura que la cantidad de televisión que ellos vean. Varias investigaciones sugieren, de hecho, que los niños que ven más televisión tienen menor rendimiento en la lectura, pero este dato a solas puede resultar equívoco. En primera instancia, afirmar que el ver televisión y el rendimiento en la lectura están relacionados no implica necesariamente que lo primero afecte a lo segundo. Quizá sea precisamente al revés; dado que un niño es un lector menos competente que otros, elige como su actividad preferida la televisión en lugar de los libros. Y lo que es más probable, tanto el hábito de ver televisión como el rendimiento en la lectura pueden ser el resultado de otros factores. Cuando los investigadores comparan a niños de inteligencia y origen socio-económico similares, la relación negativa entre ver la televisión y leer se torna menos significativa. En el caso particular de los alumnos de EGB, los ingresos del grupo familiar, el enfoque de los padres sobre los medios de comunicación y las actitudes de los propios niños hacia la lectura parecen ser variables más relevantes para predecir los rendimientos eventuales en el área de la lectura, y no el tiempo que los niños ven la televisión. Los niños de tercer año en EGB con alto rendimiento en lectura son hijos de padres que valoran la lectura y ponen a su disposición materiales impresos. Los propios alumnos consideran la lectura una fuente de placer y aprendizaje.

Un hogar que incentiva y realza la actividad de lectura contribuye al éxito de los niños en esta actividad. Y correlativamente, un grupo familiar que ignore los medios impresos y haga hincapié en la televisión como el pasatiempo fundamental, como el maestro y el gran compañero de todos, puede bloquear el desarrollo lector de sus vástagos.

No debe considerarse la televisión como un enemigo para la educación de los niños. No soy la primera que lo dice: el problema no es el medio en sí; la forma en que se lo utiliza es lo que determina sus beneficios para los usuarios. La televisión ofrece al niño un acceso más expedito que nin- 
gún otro medio al universo de la ficción. El cine también, pero en este caso el niño debe abandonar su hogar y pagar por ver la película. Como hemos dicho, incluso los niños más pequeños enfrentados a una pantalla pueden aprehender las acciones fundamentales dentro de una historia y las reacciones de los personajes a lo que está sucediendo. El desafío educativo no consiste, aquí, en ayudar a los niños a que descifren el sentido de lo que se les muestra, sino en enseñarles a relacionar lo que han visto y oído en la televisión con el mundo de fuera de la pantalla. Todo consiste en recordarles lo que es la figura y lo que es el fondo.

\section{PRACTICAS SUGERIDAS}

Hay muchas formas posibles de enriquecer la experiencia televisiva infantil. Cada progenitor y cada maestro con niños a su cargo debe decidir qué tipo de intervención se requiere en cada caso, si es que es necesaria. Los niños disfrutan viendo la televisión. Puede que algunos de nosotros optemos por dejar que la disfruten sin más. En el extremo opuesto, hay arduos defensores de un programa formal, diseñado para convertir a los niños en espectadores críticos e informados. Entre ambas queda una postura en virtud de la cual los adultos pueden utilizar las historias televisadas y las películas para enseñar algo a sus hijos, para aprender ellos algo y para divertirse en compañía de los niños.

\section{Ver la televisión juntos}

El hecho puro y simple de acompañar a un niño cuando ve un programa de televisión o una película puede ir en beneficio de su capacidad de atención. Puede que el niño sienta que la presencia de un adulto allí junto a él, legitima lo que está haciendo y esto lo lleve a considerarlo algo más serio. También puede que se sientan bien por el sencillo hecho de tenerle a usted con ellos. Desde la perspectiva adulta, la actividad nos sirve para determinar qué están viendo y oyendo nuestros hijos, y de qué clase de personajes y fantasías son testigos.

\section{Charla ante la pantalla}

La comprensión infantil sale beneficiada a su vez cuando el adulto hace un esfuerzo por clarificarle o interpretar para él la imagen en movimiento, como puede ser explicarle la importancia de algún acontecimiento en particular o indicarle su relación con ciertos acontecimientos precedentes. Aun cuando puede que la charla no fluya con igual libertad que cuando es usted el que le cuenta una historia, al seguir juntos un episodio televisivo o una película hay tiempo suficiente para compartir con ellos nuestras propias reacciones y atender a las de ellos. Este proceso de intercambio nos permite descubrir qué aspectos de un argumento en particular les llaman la atención. Además, ello nos brinda la oportunidad de incorporar nuestros propios sentimientos y valores o de corregir sus nociones equivocadas.

1. ¿Se hallan los niños comprometidos con el dilema a que se enfrenta 
uno de los personajes? Pregúnteles si harían ellos lo que el personaje ha hecho y por qué.

2. Determine si perciben las motivaciones de un personaje: pregúnteles por qué hizo ese personaje tal o cual cosa.

3. Explore los juicios infantiles respecto a las acciones desarrolladas por los personajes: pregúnteles, ¿te parece que lo que ha hecho fue una buena idea, una mala idea? o ¿qué te parece?

\section{Juegos con un proyector de vídeo}

El aparato de vídeo es un ingenio formidable para desarrollar variados juegos narrativos. Es posible jugar a infinidad de juegos de adivinanza por la vía de detener y echar a andar nuevamente una historia en distintos puntos.

1. Pare una cinta de vídeo sobre un misterio policial, por el tiempo suficiente para que cada espectador prediga quién cometió el crimen, dónde están ocultas las joyas, etc., y explique en qué se basa su predicción.

2. Se puede interrumpir un episodio de aventuras para especular sobre lo que va a ocurrir a continuación: ¿cómo hará el héroe para salvarse o la heroína para burlar al villano?

3. Se puede revisar más de una vez una historia que haya despertado entusiasmo en el niño. $Y$ en cada ocasión haga que los niños vean o escuchen algo nuevo.

4. Repase a la vez las técnicas de producción: determine quién es el que mejor advierte los cambios de escena o en los efectos visuales especiales.

Puede que detener la acción dramática a mitad de camino resulte frustrante. Pero no olvide que la mayoría de los niños actuales han lidiado desde pequeñitos con las pausas publicitarias.

\section{Generar algo nuevo}

La televisión y el cine pueden resultar un factor sumamente estimulante para los jóvenes espectadores. ¿Por qué no permitir que liberen su energía creativa?

1. Redacción de reseñas televisivas of filmicas.

- ¿Por qué limitar a los niños a hacer críticas de los libros que leen? También se los puede impulsar a poner por escrito sus vivencias ante un producto televisivo o un film. La experiencia les permitirá además adquirir consciencia de lo que supone una producción visual de cierta complejidad.

- Primero destine algo de tiempo a discutir qué información proveniente de un programa televisivo o una película debe incluirse en una reseña crítica de ellas. Para ser rigurosamente justos con ambos medios audiovisuales, puede solicitarles que comenten los diversos elementos que intervienen en ambos como la banda sonora, el decorado, el vestuario y la actuación.

- Si existe una versión novelada del producto, algunos niños podrían hacer la crítica del libro y otros del producto en pantalla y luego comparar sus notas respectivas.

2. Escenificar dramas.

- Anime a los niños a escribir pequeños guiones en el estilo de los programas televisivos o películas de moda: por ejemplo, al estilo de las tele- 
novelas, las comedias, las aventuras de superhéroes o las de ciencia ficción. Distintos niños deberán hacerse responsables de la actuación, el vestuario, la iluminación, la música, etc., dependiendo de la mayor o menor complejidad de la producción que se decida montar.

- Los interesados en los anuncios comerciales pueden desarrollar nuevos productos, elaborar envoltorios posibles e intentar venderlos a sus compañeros de clase o sus amigos.

- El público espectador puede votar para definir cuál de los productos promocionados desean comprar y cuál no.

- Haga que un tercero grabe en cinta de vídeo el comportamiento de los niños de modo que luego puedan verse ellos mismos en la pantalla. En ocasiones, los colegios disponen de equipo de vídeo y una persona especializada que puede enseñar a aquellos alumnos motivados cómo utilizar la cámara. Algunos servicios comunitarios de televisión por cable ofrecen al público el alquiler de equipos de vídeo y acceso a sus estudios.

3. Hacer pantomimas.

- Cada individuo o grupo puede planear una historia muy corta para representarla recurriendo a la gestualidad, la expresión facial y el movimiento corporal. Hablar está prohibido, pero quizá resulte aconsejable incorporar efectos sonoros y accesorios diversos.

- Adapte las reglas a las capacidades infantiles.

- Haga que los espectadores reproduzcan en palabras lo que ellos creen que ha tenido lugar.

- Enséñeles una película de algún mimo para prepararlos.

Si su propia motivación flaquea, recuerde lo siguiente: aquellos niños que invierten más energía como espectadores obtienen los mayores dividendos.

No, pero he visto la película. L. Krasny Brown CLEE, 1990, 5, pp. 7-23

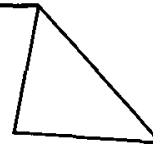

Datos sobre la autora: L. Krasny-Brown es psicóloga de la educación y trabajó durante cinco años en la Harvard Graduate School of Education co-dirigiendo con Howard Gardner un programa de investigación sobre la comprensión por los niños de la narración a través de los medios.

Articulo original: «No, but I saw the movie" En L. Krasny-Brown, Taking advantage of media. Boston, Mass. Routledge \& Kegan Paul, 1986, 66-82 (Trad. cast. en Madrid: Visor, en prensa). Traducción: Jaime Collyer.

(C) De todos los artículos. Deberá solicitarse por escrito autorización de CL\&E y de los autores para el uso en forma de facsímil, fotocopia o cualquier otro medio de reproducción impresa. CL\&E se reserva el derecho de interponer las acciones legales necesarias en aquellos casos en que se contravenga la ley de derechos de autor. 